\title{
Designing and Application of a Renewable Energy Model for a Tertiary Care Research Hospital
}

\author{
${ }^{1}$ Shakti Kumar Gupta, ${ }^{2}$ Jitendar Sharma, ${ }^{3}$ Vikas Varma, ${ }^{4}$ BS Anand
}

\begin{abstract}
Renewable energy can be harnessed from Solar and Wind energy to augment and substitute for the conventional energy for Healthcare institutes. This is economical and plentily available. This case study aims to design a Renewable energy model. Here various structural data and available expenditure has been utilized from a tertiary care hospital.
\end{abstract}

Keywords: Solar energy, Renewable energy, Wind energy, Sun hours.

How to cite this article: Gupta SK, Sharma J, Varma V, Anand BS. Designing and Application of a Renewable Energy Model for a Tertiary Care Research Hospital. Int J Res Foundation Hosp Healthc Adm 2014;2(1):57-61.

Source of support: Nil

Conflict of interest: None

\section{INTRODUCTION}

Renewable energy pertains to the energy potential available naturally in the five elements of nature. However, this potential can be harnessed from Sun and Air in the form of Solar Energy and Wind Energy for the benefit of man. This unique concept has few advantages like low cost of investment; zero running cost, low maintenance cost, and promotion of energy conservation with subsequent protection of environment.

Healthcare Institutions in particular have a very highenergy demand. This is due to high requirement in thermally conditioned areas like operating rooms, blood bank, laboratories and intensive care units and also because of the necessity of running the healthcare facility 24 hours a day 365 days a year. The risk associated with power crunch can

\footnotetext{
${ }^{1} \mathrm{Head},{ }^{2}$ Clinical Faculty, ${ }^{3}$ Independent Consultant

${ }^{4}$ Superintending Engineer

${ }^{1}$ Department of Hospital Administration and Medical Superintendent, Dr RP Centre for Ophthalmic Sciences All India Institute of Medical Sciences, New Delhi, India

${ }^{2}$ The University of Adelaide, Adelaide, South Australia, Australia

${ }^{3}$ Department of Renewable Energy, Government of India, New Delhi, India

${ }^{4}$ Department of Engineering, All India Institute of Medical Sciences, New Delhi, India
}

Corresponding Author: Jitendar Sharma, Clinical Faculty The University of Adelaide, Adelaide, South Australia, Australia e-mail: Jitendra9000@gmail.com be in terms of both life and money. Hence, it is a demand of the day to explore the option of generation of renewable energy - not only to meet the growing demands and to save cost but also to have a standby in times of scarcity.

The most popular forms of renewable energy are Solar Energy and Wind Energy and amongst the available technologies- Solar Photovoltaic Systems, Solar Thermal Concentrator Systems and Wind Energy generation systems are most popular. Thanks to the ever-progressing technology, all these can be easily and safely installed on the rooftops of the buildings and generated energy could be channelized to meet the needs of a facility.

Thus in the seed of renewable energy, lie the following solutions:

a. Solar concentrators: For powering the chillers which contribute to an extent of $50 \%$ to the total energy requirement in hospitals.

b. Solar photovoltaic systems: For powering the electrical need during the day.

c. Wind energy systems: For powering during both day and night.

The technical and financial viability of the projects needs to be explored in detail and the net benefit has a wide range, depending upon the area available for installation and the geographical location of the healthcare facility. Renewable energy replaces conventional fuels in four distinct areas: power generation, hot water/ space heating, transport fuels, and rural (off-grid) energy services.

Power generation: Renewable energy provides 18\% of total electricity generation worldwide. Renewable power generators are spread across many countries, and wind power alone already provides a significant share of electricity in some areas. Some countries get most of their power from renewable sources, including Iceland (100\%), Brazil (85\%), Austria (62\%), New Zealand (65\%), and Sweden (54\%).

Heating: Solar hot water makes an important contribution in many countries, most notably in China, which now has $70 \%$ of the global total. Most of these systems are installed on multi-family apartment buildings and meet a portion of the hot water needs of an estimated 50 to 60 million households in China. Worldwide, total installed solar water heating systems meet a portion of the water heating needs of over 70 million households. 
Wind energy: Airflows can be used to run wind turbines. Modern wind turbines range from around $600 \mathrm{~kW}$ to $5 \mathrm{MW}$ of rated power, although turbines with rated output of 1.5 to $3 \mathrm{MW}$ have become the most common for commercial use. Globally, the long-term technical potential of wind energy is believed to be five times total current global energy production, or 40 times current electricity demand. This could require large amounts of land to be used for wind turbines, particularly in areas of higher wind resources. Wind power is renewable and produces no greenhouse gases during operation, such as carbon dioxide and methane.

Solar energy: Solar power is the conversion of sunlight into electricity, either directly using photovoltaic (PV), or indirectly using concentrated solar power (CSP). CSP systems use lenses or mirrors and tracking systems to focus a large area of sunlight into a small beam. PV converts light into electric current using the photoelectric effect.

\section{OBJECTIVES}

a. To study the electrical load requirement and load patter of Tertiary Care Research Hospital.

b. To see the feasibility of application of renewable energy like sun energy and wind energy at Tertiary Care Research Hospital to partly cover the power needs.

c. To calculate the open space and terrace space available at Tertiary Care Research Hospital and its centers.

d. To suggest a technical solution in terms of number of solar panels and windmills required for generating the needed output.

e. To suggest a financial model of the project covering aspects like- approximate initial investment, annual savings due to usage of renewable energy and break even time.

\section{METHODOLOGY}

1. The total appliance load (electrical load) was estimated. This includes chillers, pumps, lighting, air conditioners, servers, etc.).

2. Graphs and tables depicting load and cost tabulated on time line (annual/monthly/daily). As load could be different on different days of the week, daily load mapped in weekly trends.

3. Peak load (max. load) and base load (average load) was estimated.

4. Total area on terrace of all centers and main building was measured.

5. Maximum number of solar panels and wind machines that could be installed was estimated.

6. Data regarding total solar and wind energy available at Tertiary Care Research Hospital at various months in the year was gathered from Indian Meteorological Department.

7. Panels and wind machines capacity most suitable for Tertiary Care Research Hospital was identified and power that could be generated by the given number of machine was estimated.

8. To what extent the power needs could be covered by the renewable sources was calculated.

9. Approximate investment required and net savings estimation was done.

Based on the calculations are study results, it was ascertained if renewable energy could be partly or fully cover the electrical power requirements of Tertiary Care Research Hospital and if yes, to what extent is this coverage possible. The study brought out the technical viability regarding the expansion of renewable energy work in future and the financial breakeven point in years so as to estimate the annual net savings after breakeven.

\section{DATA ANALYSIS}

For a renewable energy project, the following categories of data is required:

a. Demand data (based on electrical connected load).

b. Structural data (based on land area available for installation of renewable energy equipment).

c. Renewable energy availability data (based on energy sources and geographical location of the institution).

Once the data has been collection, financial modeling is carried out, which consists of:

a. Investment required for the project.

b. Estimated savings calculated.

c. Break even threshold.

\section{PROJECT MILESTONES}

1. Estimation of need-from in house engineering records.

2. Collecting and analyzing energy availability data - from sources, like Indian Metrological Department, Satellite records and weather archives.

3. Arriving at the solution which is most viable - both technically and financially.

In this study, the following data sets were collected and analyzed:

(A) Demand data:

\begin{tabular}{lcc}
\hline HT bulk demand at & Tertiary Care Research Hospital and centres \\
\hline Time period (2010) & Units consumption & Bill amount (₹) \\
& (KWH) & \\
\hline January & 2317512 & 10697231 \\
February & 2686494 & 12358444 \\
March & 2696977 & 10738225 \\
April & 4537842 & 13824779 \\
May & 3547701 & 17844547 \\
June & 3809735 & 18981266 \\
July & 4040170 & 19969921 \\
August & 5529061 & 22706497 \\
September & 4642505 & 22520035 \\
October & 4204695 & 20710983 \\
November & 3523539 & 17753320 \\
December & 2686404 & 13965711 \\
\hline Total (annual) & 44222635 & 202070959 \\
Average (monthly) & 3623912 & 16839247 \\
\hline
\end{tabular}




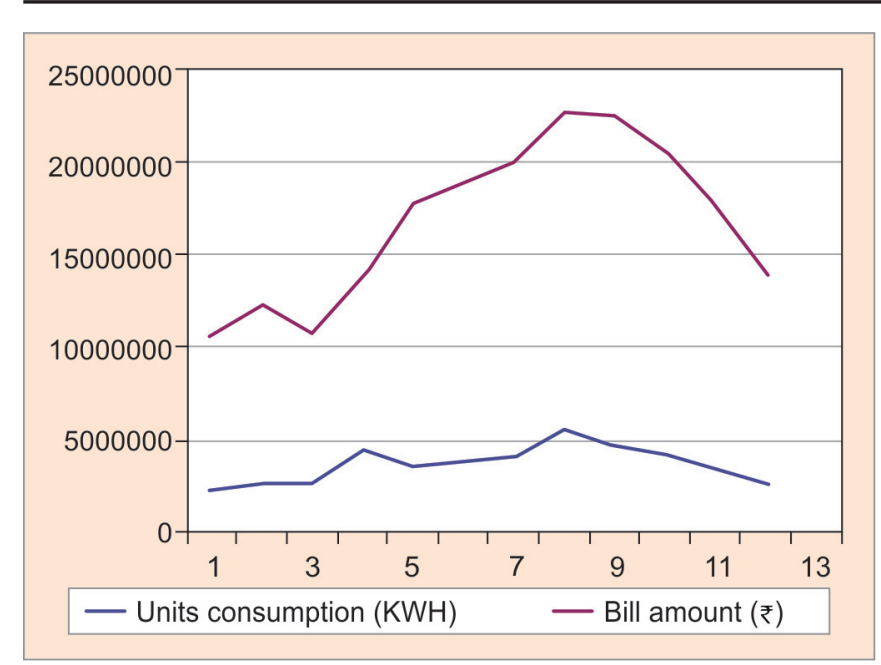

(B) Structural data:

\begin{tabular}{lll}
\hline Facility & $\begin{array}{l}\text { Roof top area } \\
\text { (sq. } \mathrm{ft})\end{array}$ & $\begin{array}{l}\text { Roof top area } \\
\text { (sq. } \mathrm{mt} \text { ) }\end{array}$ \\
\hline $\begin{array}{l}\text { Tertiary Care Research } \\
\text { Hospital (Ward block) }\end{array}$ & 32741 & 3042 \\
$\begin{array}{l}\text { Tertiary Care Research } \\
\text { Hospital (OPD Block) }\end{array}$ & 54600 & 5074 \\
Teaching Block & 45960 & 4271 \\
Para Clinical Block & 63700 & 5920 \\
Dr RP Centre (Ward Block) & 17538 & 1630 \\
Dr RP Centre (OPD Block) & 28890 & 2685 \\
Dr Brairch & 23700 & 2200 \\
Cardio-Neuro Centre & 58600 & 5446 \\
Cardio-Neuro Tower & 6900 & 640 \\
\hline Total area available & 332629 & 30908 \\
\hline
\end{tabular}

\section{Renewable Energy Availability Data}

The two main sources of energy, as discussed earlier are solar and wind. Following are the aspects that are considered while estimating the energy availibility due to these sources.

\section{Solar Energy}

- Arc path of sun

- Solar radiation (watts/sq.mt)

- Sun hours/day.

New Delhi receives approximately 5 full sun hours of solar radiation every day. This energy might be obscured by atmospheric haze and cloud cover which has to be anticipated in predicting power output from solar energy collectors. This includes time period when solar radiation is of adquate intensity based on the arc path of the sun in New Delhi sky.

\section{Wind Energy}

- Wind speed (meters/sec)
- Wind direction

- Wind spectrum analysis.

Average speed for last 30 years in New Delhi $=3.7$ meters/sec. Predominant wind flow direction is from West during the day and North-West, West in the night. It is to be noted here that for energy generation, 8 meters/second is considered as a good wind speed.

Searching for appropriate technologies: The study considered the application of solar photovoltaic cells, solar thermals and roof top wind generators. The following are specifications of the technologies that were studied:

1. Solar photovoltaic cells:

- SW 230 PV panels

- Peak power watts 230

- Peak power voltage 29.6

- Peak power current 7.76

- Open circuit voltage 36.9

- Max system voltage 600

- Series fuse rating 15 a

- Length $1675 \mathrm{~mm}$, width $1001 \mathrm{~mm}$

- Depth $34 \mathrm{~mm}$

- Weight $22 \mathrm{~kg}$

- System efficiency 12 to $15 \%$.

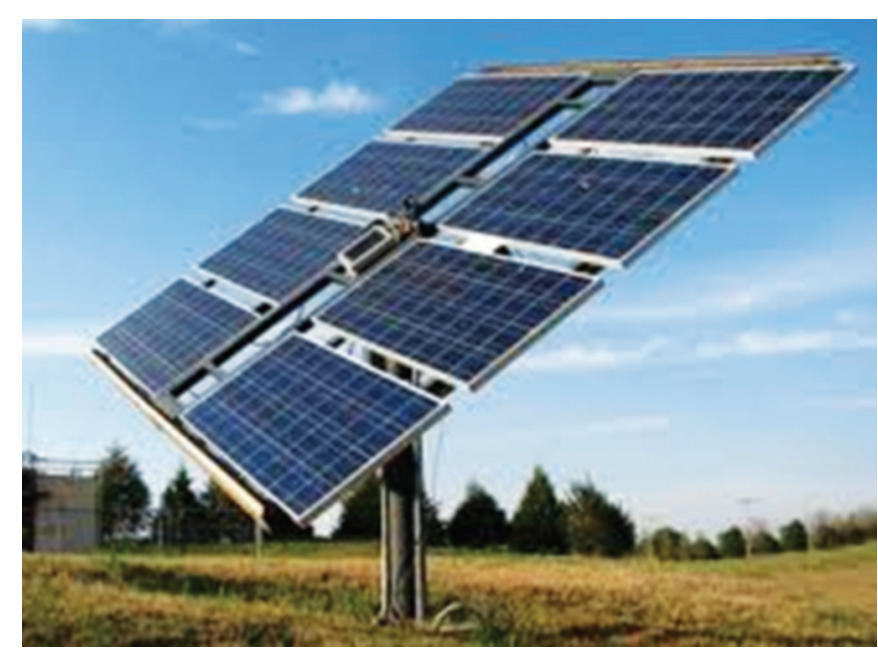

2. Solar thermals:

- Powered by renewable solar energy

- No emissions

- Automated system control and monitoring

- Produces temperatures as high as $392^{\circ} \mathrm{F}\left(200^{\circ} \mathrm{C}\right)$

- Collector length $-12 \mathrm{ft}$

- Collector width $-5 \mathrm{ft}$

- Total reflector area $-60 \mathrm{ft}^{2}$

- Operating temp range -122 to $500^{\circ} \mathrm{F}$

- Collector weight $-150 \mathrm{lb}$ 


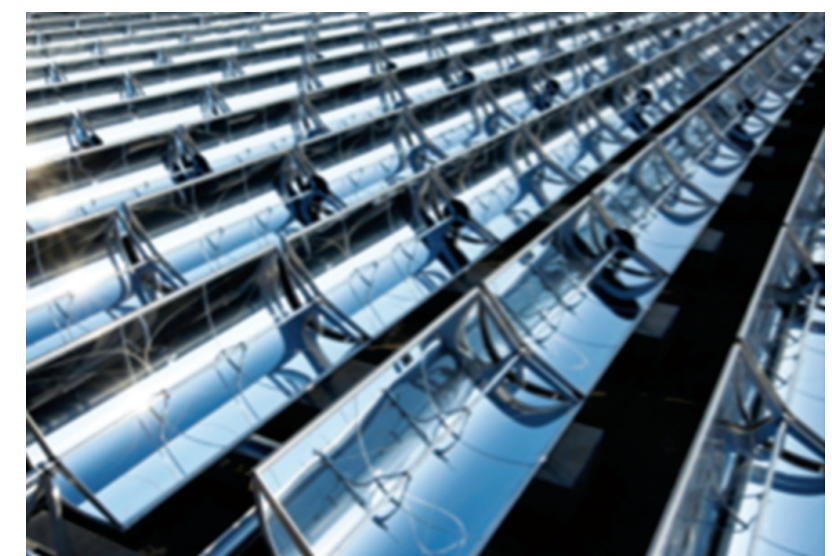

3. Wind generator:

\begin{tabular}{|c|c|}
\hline \multicolumn{2}{|c|}{ Physical parameters } \\
\hline Turbine diameter (average) & $2.75 \mathrm{~m} \mathrm{(108")}$ \\
\hline Turbine height & $4.2 \mathrm{~m}\left(165^{\prime \prime}\right)$ \\
\hline Tower (standard) & $5.5 \mathrm{~m}\left(18^{\prime \prime}\right)$ \\
\hline Turbine weight (w/generator) & $190 \mathrm{~kg}$ \\
\hline Tower weight & $540 \mathrm{~kg}$ \\
\hline Roof mount weight (steel) & $280 \mathrm{~kg}$ \\
\hline Roof mount weight (aluminum ) & $90 \mathrm{~kg}$ \\
\hline Shipping size & 7.4 CBM \\
\hline
\end{tabular}

\begin{tabular}{ll}
\hline \multicolumn{2}{c}{ Performance parameters } \\
\hline Start-up wind speed & $2.5 \mathrm{~m} / \mathrm{s}(5 \mathrm{mph})$ \\
Cut-in wind speed & $3.5 \mathrm{~m} / \mathrm{s}(7.5 \mathrm{mph})$ \\
Cut-out wind speed & $25 \mathrm{~m} / \mathrm{s}(56 \mathrm{mph})$ \\
Rated wind speed & $12 \mathrm{~m} / \mathrm{s}(27 \mathrm{mph})$ \\
Max (survival) wind speed & $50 \mathrm{~m} / \mathrm{s}(110 \mathrm{mph})$ \\
Rated lifetime & 20 years \\
\hline
\end{tabular}

\begin{tabular}{ll}
\hline \multicolumn{1}{c}{ Generator (grid tie version) } \\
\hline Type & Synchronous, permanent \\
& magnetic, 3-phase, 16 poles \\
Rated voltage & $270 \mathrm{~V}$ \\
Rated temperature & $<55^{\circ} \mathrm{C}$ \\
Revolutions per minute (RPM) & 120 \\
Drive type & Direct-drive \\
Protection & IP54 \\
Insulation & Class B \\
Weight & $90 \mathrm{~kg}$ \\
\hline
\end{tabular}

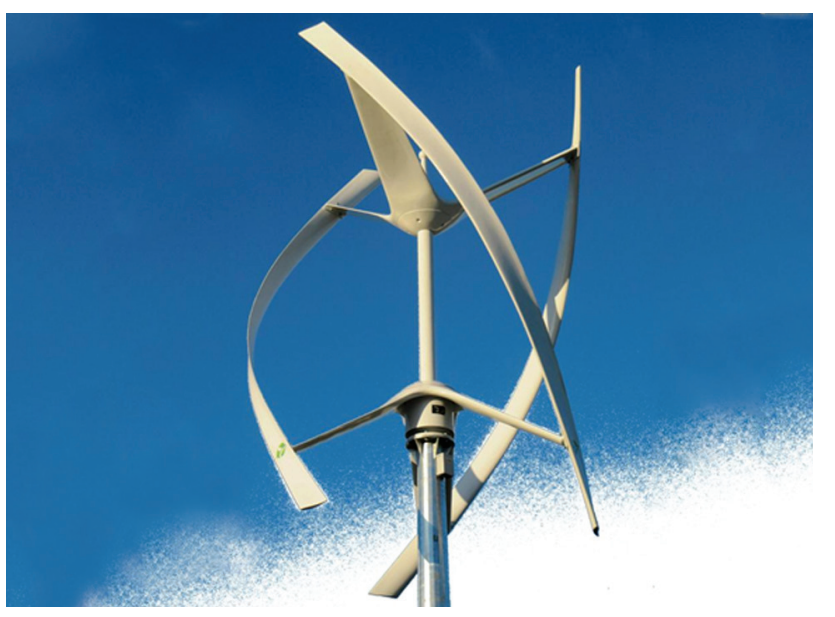

It was found in the study that solar photovoltaic system is less efficient that solar thermals. Although each Wind Turbine generate $4 \mathrm{~kW}$ rated power, due to low wind speed at New Delhi, it was not considered to be the optimal solution.

\section{Salient Features of Proposed Renewable Energy Solution for Tertiary Care Research Hospital}

\section{Technical Model}

- 1700 solar concentrators with trackers moving from east to west

- Systems output $5000 \mathrm{~kW}$

- Proposed systems efficiency: $58 \%$

- Total air conditioning load at Eye centre, cancer centre, CN centre of Tertiary Care Research Hospital, 6000 Tones $/ 6400 \mathrm{~kW}$

- Proposed solution will meet upto $90 \%$ of air-conditioning load.

\section{Investment Model}

- Investment ₹ 23.5 crore

- Total capacity of $5066 \mathrm{~kW}$

- Actual yearly output 9,652,250 kW

- Subsidy available ₹ 5.5 crore

- Per annum energy saving in excess of ₹ 5 crore

- Over 25 years saving ₹ 140 crore Key assumeptions used in the study:

- Saving of power charges paid to Electricity Utility Company ₹ 4.10 per kWH

- Escalation of power charges 15\% year 1, thereafter $3 \%$ pa

- CDM credits eligibility

- Accelerated depreciation for off-grid solution $80 \%$

- Corporate Tax Rate $33.22 \%$

- Cash Flow discounting rate $10 \%$

- Annual Maintenance Cost 1\%

- Green Cess Saving ₹ 0.05 per unit

- Subsidy as per MNRE regulations.

\section{Benefits and Government of India Incentives for a} Renewable Energy Project

- Solar PV — ₹ 70 per Watt (Restricted to maximum of $100 \mathrm{kWp})$

- Solar Thermal - 30\% (Subject to maximum of ₹ 5400 per sq meter of solar concentrator)

- Wind and solar hybrid — ₹ 1 Lakh per $\mathrm{kW}$ (restricted to $50 \mathrm{kWp}$ )

- Accelerated depreciation under section 32 of income tax act - $80 \%$

- Saving in power bill

- Comply to regulatory requirement of GREEN building

- Additional power generation capability

- Better peak load energy management 
- Long life of assets up to 40 years

- Low maintenance assets.

\section{RESULTS}

This Tertiary Care Research Hospital being one of the largest tertiary care hospitals in the country with more than 2000 beds, and has a massive annual electrical consumption. The study brought our the fact that energy equivalent to 2 to 3 months of electrical consumption could be obtained for free using renewable energy solutions which means an annual saving of up to ₹ 5 crores. The energy production is estimated to be around 1 crore units annually. The options explored were Wind Energy, Photovoltaic aided light energy and thermal energy. From the data obtained from Indian Meteorological Department, it was seen from the last 30 years average wind velocity that wind energy is not a technically viable solution for New Delhi. However, the results of thermal energy application using Solar Thermals could be a technically and financially viable solution.

\section{CONCLUSION}

The efficiency of the renewable energy systems, the saving in cost of running a healthcare facility which eventually reaches the patients in terms of increased affordability, encouraging government regulations and incentives for using renewable energy and the protection of environment are some of many features that demand an eager and positive look toward this revolutionary approach to the energy systems. 